\title{
GEOCHEMICAL METHODS
}

Bulk diamictites and those containing malachite were lightly crushed and leached by $18 \mathrm{M} \Omega$ water five times over one day period and supernatants collected. $2 \mathrm{M} \mathrm{HCl}$ was added to the residue and shaken for hours before supernatants were collected. The sulfate in malachite was extracted from both water-treated and $\mathrm{HCl}$-treated supernatants and was precipitated as barite. The $\mathrm{HCl}$-treated residues containing barite were washed by $18 \mathrm{M} \Omega$ water three times then treated with diethylene triamine pentaacetic acid (DTPA) to extract sulfate to be re-precipitated as pure barite. All initially precipitated barite were treated with DDARP method (Bao, 2006), a necessary step for purification of sulfate. The $\mathrm{Cu}_{2} \mathrm{~S}$ in the acid and in the DDARP treated residues was extracted as $\mathrm{Ag}_{2} \mathrm{~S}$ using a modified chromium reduction method (Canfield et al., 1986). The $\delta^{18} \mathrm{O}$ and $\delta^{17} \mathrm{O}$ of barite were simultaneously measured using laser-fluorination method to obtain the $\Delta^{17} \mathrm{O}$ for sulfate (Bao and Thiemens, 2000). The $\delta^{18} \mathrm{O}$ of barite was obtained using TCEA method. All the above experiments were done at LSU. The $\delta^{34} \mathrm{~S}_{\text {of }} \mathrm{BaSO}_{4}$ and $\mathrm{Ag}_{2} \mathrm{~S}$ was analyzed at University of Maryland. The error bars for the $\delta^{18} \mathrm{O}$ and $\delta^{34} \mathrm{~S}$ of sulfate are smaller than $\pm 0.5 \%$ and $\pm 0.3 \%$ respectively.

Table DR1. The $\delta^{18} \mathrm{O}, \Delta^{17} \mathrm{O}$, and $\delta^{34} \mathrm{~S}$ for carbonate-associated sulfate in malachite (MAS) and barite in chalcocite clasts, the $\delta^{13} \mathrm{C}$ and $\delta^{18} \mathrm{O}$ for carbonates in malachite, and the $\delta^{34} \mathrm{~S}$ for chalcocite in the Purple Shale Member of a Neoproterozoic diamictite, Kaiyang, central Guizhou.

\begin{tabular}{lccccc}
\hline Sample & $\begin{array}{c}\boldsymbol{\delta}^{\mathbf{1 8}} \mathbf{O}-\mathbf{S O 4} \\
(\mathbf{V S M O W})\end{array}$ & $\Delta^{\mathbf{1 7}} \mathbf{O - S O 4}$ & $\begin{array}{c}\boldsymbol{\delta}^{\mathbf{3 4}} \mathbf{S - S O 4} \\
(\mathbf{V C D T})\end{array}$ & $\begin{array}{c}\boldsymbol{\delta}^{\mathbf{1 3}} \mathbf{C - C O 3} \\
(\mathbf{V P D B})\end{array}$ & $\begin{array}{c}\boldsymbol{\delta}^{\mathbf{1 8}} \mathbf{O}- \\
\mathbf{C O 3} \\
\text { (VPDB) }\end{array}$ \\
\hline Malachite patches & & & & & \\
KY-08-1-1 & -16.9 & -0.35 & -12.6 & -11.3 & -5.7 \\
KY-08-1-2-HCl & -16.4 & -0.06 & -12.1 & -11.2 & -5.9 \\
KY-08-1-2-W & -5.7 & -0.11 & -6.7 & & \\
KY-08-1-a-HCl & -17.6 & -0.15 & -8.6 & -10.8 & -6.2 \\
KY-08-1-a-W & -0.4 & n. a. & -8.7 & & \\
KY-08-1-b & -18.0 & -0.20 & -11.3 & -7.4 & -9.0 \\
KY-08-1-b-g-W & -3.9 & -0.11 & -7.3 & & \\
KY-08-1-c & -16.1 & -0.07 & -10.6 & -3.4 & -11.1 \\
KY-08-1-d & -18.7 & -0.21 & -10.9 & -9.7 & -6.5 \\
KY-08-1-e & -17.3 & -0.22 & -9.9 & -10.0 & -7.0 \\
KY-08-1-f & -17.7 & -0.20 & -9.8 & -10.4 & -5.7 \\
KY-08-1-g & & & & -6.0 & -9.2
\end{tabular}




$\begin{array}{lccccc}\text { KY-08-1-h } & -14.9 & -0.18 & -10.3 & -2.9 & -11.5 \\ \text { KY-08-1-h+i-W } & -14.2 & \text { n. a. } & -5.4 & & \\ \text { KY-08-1-i } & -8.3 & \text { n. a. } & -5.7 & -2.6 & -11.5 \\ \text { KY-08-2-a } & -9.5 & \text { n. a. } & -6.0 & -2.4 & -11.2 \\ \text { KY-08-2-b } & -9.5 & \text { n. a. } & -8.5 & -2.5 & -11.8 \\ \text { KY-08-2-W } & -2.0 & \text { n. a. } & -3.2 & & \\ \text { KY-08-3-HCl } & 4.1 & \text { n. a. } & \text { n. a. } & -2.9 & -13.1 \\ \text { KY-08-3-W } & 4.6 & 0.01 & \text { n. a. } & & \end{array}$

Barite associated with chalcocite clasts

\begin{tabular}{|c|c|c|c|}
\hline KY-08-1-B & -18.9 & -0.24 & -11.7 \\
\hline KY-08-1-1-B-1 & -17.8 & -0.22 & -12.0 \\
\hline KY-08-1-1-B-2 & -17.4 & -0.33 & -11.7 \\
\hline KY-08-1-1-B-3 & -19.6 & -0.19 & -11.7 \\
\hline KY-08-1-1-B-4 & -17.9 & -0.23 & -11.7 \\
\hline KY-08-1-b-B & -18.5 & -0.26 & -11.9 \\
\hline KY-08-1-c-B & -17.5 & -0.24 & -11.0 \\
\hline KY-08-1-d-B & -19.7 & -0.21 & -12.1 \\
\hline KY-08-1-e-B & -18.8 & -0.20 & -12.1 \\
\hline KY-08-1-f-B & -19.5 & -0.20 & -12.0 \\
\hline KY-08-1-g-B & -20.3 & -0.24 & -10.7 \\
\hline KY-08-1-h-B & -17.8 & -0.18 & -10.7 \\
\hline KY-08-1-i-B & -14.5 & -0.18 & -9.7 \\
\hline KY-08-2-a-B & -7.5 & -0.21 & -2.7 \\
\hline KY-08-2-b-B & -6.1 & -0.19 & -3.2 \\
\hline \multirow{2}{*}{\multicolumn{4}{|c|}{$\begin{array}{l}\text { Residual chalcocite } \\
\left(\mathrm{Cu}_{2} \mathrm{~S}\right)\end{array}$}} \\
\hline & & & \\
\hline KY-08-1-1-Ag2S & & & -12.0 \\
\hline KY-08-1-c-Ag2S & & & -12.1 \\
\hline KY-08-1-d-Ag2S & & & -12.7 \\
\hline KY-08-1-e-Ag2S & & & -11.7 \\
\hline KY-08-1-f-Ag2S & & & -11.8 \\
\hline KY-08-1-g-Ag2S & & & -10.6 \\
\hline KY-08-1-h-Ag2S-1 & & & -12.5 \\
\hline KY-08-1-h-Ag2S-2 & & & -12.1 \\
\hline KY-08-1-i-Ag2S & & & -12.9 \\
\hline KY-08-2-a-Ag2S & & & -12.8 \\
\hline KY-08-2-b-Ag2S & & & -12.8 \\
\hline KY-08-2-CuS-Ag2S & & & -12.7 \\
\hline
\end{tabular}

Sample "KY-08-1" is a big piece of the diamictite containing chalcocite clasts and malachite seams; "KY-08-2" is a piece of diamictite $10 \mathrm{~cm}$ above "KY-08-1"; and sample "KY-08-3" is a piece of diamictite $15 \mathrm{~cm}$ above "KY-08-2". "W" stands for sulfate extracted by water only, while " $\mathrm{HCl}$ " for those further treated with $2 \mathrm{M} \mathrm{HCl}$ after water extraction. Most of the malachite 
samples were from one single outcrop "KY-08-1". The data show that $\delta^{18} \mathrm{O}$ and $\delta^{34} \mathrm{~S}$ values of MAS are much higher for the water-extracted ones than for the HCl-leached ones.

\section{The $\delta^{13} \mathrm{C}$ and $\delta^{18} \mathrm{O}$ of Malachite}

Multiple samples of malachite-bearing diamictite in the vicinity of chalcocite clasts yield a linearly inverse correlation between the $\delta^{13} \mathrm{C}$ and the $\delta^{18} \mathrm{O}$ of the bulk carbonates (Fig. 4), with one end-member characterized by low $\delta^{13} \mathrm{C}(-11.5 \%)$ and high $\delta^{18} \mathrm{O}(-5.8 \%)$ and the other by high $\delta^{13} \mathrm{C}(-3.5 \%)$ and low $\delta^{18} \mathrm{O}(-12 \%)$. The precipitation of malachite and its $\delta^{13} \mathrm{C}-\delta^{18} \mathrm{O}$ space (Fig. DR1) offer an independent clue to the formation condition of malachite. The data in Fig. DR1 suggest an apparent two-component mixing between dolostone clasts in the diamictite and the authigenic malachite at the immediate vicinity of the chalcocite clasts. Because of the relative fractions of carbonates from the two sources are difficult to estimate, we can only conclude that the malachite end-member had a low $\delta^{13} \mathrm{C}$ (lower than -11.5\%) and high $\delta^{18} \mathrm{O}$ (higher than $5.8 \%$ ), which is consistent with those of carbonates precipitated in semi-arid continental environments (Cerling and Quade, 1993), a condition probably present during the oxidation of chalcocite clasts and the precipitation of at least some of the nearby malachite in the Kaiyang diamictite.

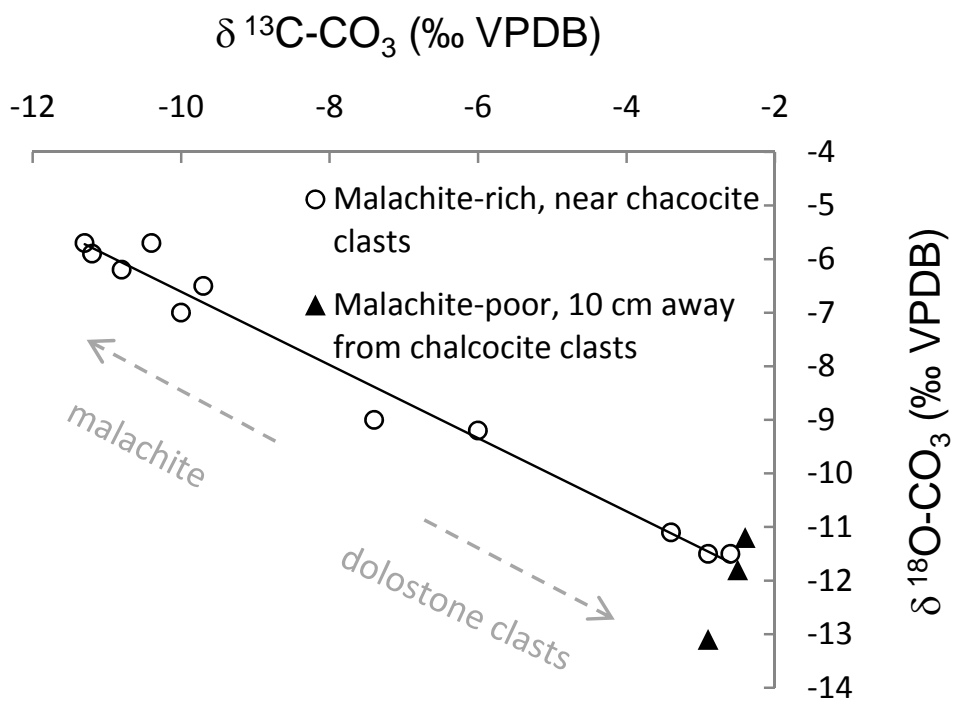

Figure DR1. The $\delta^{13} \mathrm{C}$ and $\delta^{18} \mathrm{O}$ of multiple pieces of malachite-bearing diamictite in the vicinity of chalcocite clasts in the upper massive part of the Kaiyang diamictite, Guizhou, China. The $\delta^{13} \mathrm{C}$ and $\delta^{18} \mathrm{O}$ of malachite were measured at Guangzhou Institute of Geochemistry, Chinese 
Academy of Sciences. The standard deviation for the $\delta^{13} \mathrm{C}$ and $\delta^{18} \mathrm{O}$ of malachite are both smaller than $\pm 0.1 \%$.

\section{References}

Bao, H.M., 2006, Purifying synthetic barite for oxygen isotope measurement by dissolution and reprecipitation in a chelating solution: Analytical Chemistry, v. 78, p. 304-309.

Bao, H.M., and Thiemens, M.H., 2000, Generation of $\mathrm{O}_{2}$ from $\mathrm{BaSO}_{4}$ using a $\mathrm{CO}_{2}$-laser fluorination system for simultaneous analysis of $\delta^{18} \mathrm{O}$ and $\delta^{17} \mathrm{O}$ : Analytical Chemistry, v. 72, p. 4029-4032.

Canfield, D.E., Raiswell, R., Westrich, J.T., Reaves, C.M., and Berner, R.A., 1986, The use of chromium reduction in the analysis of reduced inorganic sulfur in sediments and shales: Chemical Geology, v. 54, p. 149-155.

Cerling, T.E., and Quade, J., 1993, Stable carbon and oxygen isotope in soil carbonates, in Swart, P.K., and al., e., eds., Climate change in continental isotopic records, Volume 78, American Geophysical Union Geophysical Monograph, p. 217-231. 